\title{
THE EFFECT OF CLUTCH SIZE AND ANT ATTENDANCE ON EGG GUARDING BY ENTYLIA BACTRIANA (HOMOPTERA: MEMBRACIDAE)
}

\author{
By Karen L. Olmstead ${ }^{1}$ and Thomas K. Wood ${ }^{2}$
}

Subsocial behavior is postovipositional parental care that promotes the development and survival of offspring. Subsociality is particularly common in the Membracidae (Homoptera) in which the females of many species guard eggs and nymphs from predators and parasites (Eickwort 1981, Hinton 1981, Tallamy and Wood 1986, Eberhard 1986).

A number of treehopper species also interact with ant mutualists. Treehoppers provide ants with a nutritional resource in the form of honeydew and ants provide treehoppers protection from natural enemies (Way 1963). Since the survival of offspring of many treehoppers is contingent upon protection by attendant ants (Hinton 1977, Wood 1977, 1979, 1982a, 1982b, McEvoy 1979, Fritz 1982, 1983, Bristow 1983, 1984) selection should favor females that increase the probability that their offspring will be located and tended by ants.

A number of studies have documented the influence of ants on the maternal protection of young by subsocial treehoppers. For example, female Publilia recticulata Van Duzee desert nymphs after their offspring are located by ants. By transferring protection of offspring to ants, females may produce additional clutches (Bristow 1983, 1984). Similarly, tenure with nymphs is longer for $P$. concava females that are not ant attended (McEvoy 1979). In contrast, females of a closely related species, Entylia bactriana Germar, remain with eggs (Olmstead 1984) and nymphs (Wood 1977) longer when ant attended. However, none of the above studies examined the variation in protection of eggs and nymphs throughout the

\footnotetext{
'Department of Entomology and Applied Ecology, University of Delaware, Newark, DE, 19717. Current address: Department of Entomology, University of Maryland, College Park, MD, 20742.

2Department of Entomology and Applied Ecology; and Ecology Program, School of Life and Health Sciences, University of Delaware, Newark, DE, 19717.

*Manuscript received by the editor February 21, 1990.
} 
entire reproductive period of the parent females. Two factors that vary during the reproductive span of an individual and that may result in intraspecific variation in subsocial behavior are the reproductive values of parents and offspring (Tallamy 1982).

Reproductive value (RV) is the sum of an individual's contemporary and future expected reproductive effort (Begon et al. 1986). Typically, RV is considered low at birth, high at age of first reproduction, and zero at the end of an individual's reproductive activity (Tallamy 1982). Tallamy (1982) found that the variation in maternal defense by the lacebug Gargaphia solani (Hemiptera: Tingidae) could be explained by the relative reproductive values of parent females and their young. Females defend young more aggressively with increasing age of the brood (higher RV of offspring) and later in their lives (decreasing RV of the female).

We postulated that the ovipositional patterns of ant dependent treehoppers may reflect not only ant availability but also the RV of the parent female. For example, if $E$. bactriana females guarding eggs are not located by ants, the ovipositional site may not be sufficient for maturation of young. By abandoning eggs and depositing additional clutches in other areas, females may increase the probability that at least some of their offspring will be located by ants. However, if the egg mass represents a large portion of the female's total reproductive effort, or if the female is near the end of her reproductive span, the desertion of eggs prior to hatch has high fitness consequences as few nymphs resulting from abandoned egg masses will survive (Wood 1977, Olmstead 1984). Thus, guarding of egg masses may be a function of both ant attendance and the RV of the parent female.

The first objective of our study was to determine if egg guarding by $E$. bactriana females enhances the probability of location of nymphs by ants and therefore, survival of young. Secondly, we wanted to determine which of the following factors best explains intraspecific variation in $E$. bactriana ovipositional behavior; 1) factors related to the reproductive value of the female, 2) ant mutualism, or 3) some combination of these variables. Since dependencies existed among these factors, we employed a multivariate approach to analyze the data.

In Delaware, E. bactriana overwinter as adults and are present in the field in early May. Females begin oviposition in mid May and 
most die by early July. Offspring reach maturity toward the end of July and females resulting from the spring generation begin oviposition in early August. Offspring from the summer generation overwinter.

Entylia bactriana are sap-feeding insects that feed and oviposit on composites including Canada thistle (Cirsium arvense (L.) Scop.). Our study area was a naturally occurring Canada thistle patch in the University of Delaware Woodlot, Newark, New Castle Cty., DE. Because persistent patches of Canada thistle are often of a single genotype (Holm et al. 1977), we assumed the thistle plants in our study site were clones and did not examine host plant effects on female reproductive behavior. This study was conducted May 1 through September 27, 1983.

Ant species observed tending E. bactriana nymphs and adults included Prenolepis imparis (Say), Tapinoma sessile (Say), Camponotus ferrugineus (Fab.), and two species of Formica. The interactions with ants reported here are without reference to particular species.

\section{MethodS}

To determine the number and outcome of reproductive bouts for individuals, we examined each plant daily for $E$. bactriana females. When females were located, we tagged them with numbered paper disks adhered to the pronotum with balsam glue. These tags did not perceptibly affect the treehoppers and provided a reliable method of tracking individual females. As well as examining plants for females, we recorded the following from plants on which egg masses had been deposited: plant and leaf number, presence or absence of parent female, number of eggs or nymphs present, and number and species of tending ants. We examined plants at least every other day after oviposition had ended to determine ant attendance of nymphs. This procedure was repeated during the second generation. At this time, we also censused other hosts of E. bactriana (Ambrosia artemisiifolia L. and Cirsium vulgare (Savi)) within and near the Canada thistle patch in an effort to locate previously tagged females.

From these data we determined the following for each female in both generations: the number of egg masses, the number of eggs and percent egg hatch of each mass, number of days females were observed with each egg mass, the number of days females were 
observed with attendant ants, whether females deserted eggs prior to hatch, and whether nymphs were located by ants. In a few cases, whether a female remained through egg hatch could not be determined since the first day the female was absent from the egg mass was also the first day nymphs emerged from eggs. Females were observed adding eggs to previously existing egg masses $(n=21)$ and, at times, guarding these egg masses $(n=9)$.

We used Fisher's Exact test to test for association between location of nymphs by ants and female presence at egg hatch (SAS Institute 1988). Since maturation of nymphs is dependent upon protection by ants (Wood 1977), location of nymphs by ants is a significant component of fitness for this treehopper.

To determine if desertion of eggs prior to hatch has fitness costs for $E$. bactriana, we compared percent egg hatch between masses that were and were not abandoned prior to hatch with a two-way ANOVA with female presence and generation as explanatory variables (SAS Institute 1988). We used Sidak's t-test to compare means from significant ANOVA. Prior to analysis, we examined residuals for normality and homoscedasticity and transformed percent egg hatch data (arcsine square-root).

Because dependencies existed between the variables measured on ovipositing females, we used MANOVA (SAS Institute 1988) to test whether the combined patterns of number of eggs in the mass and ant attendance differed between females that deserted their first egg mass and those that remained through hatch.

Multivariate analysis of variance detects significant differences among or between groups but does not provide information on which of the variables contribute to the observed differences. Therefore, we used a stepwise discriminant analysis (SAS Institute 1988) to determine which of these variables best predicted whether a female would abandon eggs prior to hatch. Prior to analyses, we examined residuals for marginal and multivariate normality (Johnson and Wichern 1988) and equality of covariance matrices (SAS Institute 1988).

\section{RESUltS AND DisCuSSION}

Desertion of eggs prior to hatch by $E$. bactriana is costly for two reasons. First, nymphs from egg masses abandoned by females prior to hatch are less likely to be tended by ants. All of the cohorts with 
which parent females remained through egg hatch were located by ants (spring generation, $n=170$; summer generation, $n=60$ ). Significantly fewer cohorts from egg masses abandoned by females prior to hatch were located by ants (spring generation 69.87\% $(n=83)$, $\mathrm{P}<.01$; summer generation $20.5 \%(\mathrm{n}=44), \mathrm{P}<.01$; Fisher's Exact test). The response of ants to honeydew quantity and quality has been well documented (Lanza and Krauss 1984, Sudd and Sudd 1985, Cushman and Whitham 1989). Thus, parent females may be necessary to attract ants to small nymphs that alone do not produce a large volume of honeydew.

Secondly, abandoned egg masses have lower egg hatch than do egg masses guarded by parent females. In our study, egg masses abandoned by females had lower egg hatch (spring generation, $\bar{x}=31.81 \pm 1.76 \%$; summer generation, $\bar{x}=8.26 \pm 2.75 \%$ ) than did guarded masses (spring generation, $\bar{x}=54.52 \pm 1.47 \%$; summer generation, $\bar{x}=53.17 \pm 2.85 \%, F_{(1,375)}=218.03, P<0.01$; ANOVA). Abandoned egg masses in the summer generation had significantly lower hatch than in the first generation, resulting in a significant generation by female presence interaction $\left(F_{(1,375)}=23.49, P<0.01\right.$; Sidak's t-test). Reduced egg hatch of abandoned $E$. bactriana egg masses is likely due to predation. Almost half of the abandoned egg masses in our study $(n=164)$ were partially or completely eaten before nymphs began hatching. We did not observe predation on guarded egg masses.

Although desertion of eggs prior to hatch appears to have dramatic fitness consequences for E. bactriana, almost $47 \%$ of the females $(n=353)$ in our study did not remain through hatch with their first egg mass. Desertion of egg masses may result from mothers 'abandoning' eggs, or from dispersal, mortality or disturbance of parent females. We recovered almost $20 \%$ of deserting females $(n=164)$ with a second egg mass indicating that at least some $E$. bactriana females do desert their eggs to deposit other clutches.

To evaluate the importance of RV and ant attendance for $E$. bactriana ovipositional behavior, we compared the number of eggs and ant attendance between females that guarded their first clutch through hatch and those that abandoned eggs to deposit a second clutch. Females that did not remain through hatch with their first egg mass and were not recovered with a second egg mass were not included in this analysis because we did not know if these females abandoned eggs, were preyed upon, or otherwise disturbed. 
The combined pattern of number of eggs in the mass and ant attendance differed significantly between females that did and did not remain through egg hatch with their first egg mass (Wilks' lambda $=.885, \mathrm{~F}_{(2,241)}=15.61, \mathrm{P}<0.01$; MANOVA). However, the number of eggs in the egg mass (Wilks' lambda $=.8914, \mathrm{~F}_{(1,242)}=$ $29.475, \mathrm{P}<0.01$; stepwise discriminant analysis) was the only significant predictor of female tenure with eggs. To further examine this result, we compared ant attendance between females that remained through hatch with their first egg mass and those that abandoned their first egg mass to deposit another. Less than $43 \%(n=35)$ of the females that abandoned their first egg mass were observed with attendant ants while guarding that clutch. In contrast, a significantly greater number of females that remained through hatch with their first egg mass were located by ants $(72.3 \%, \mathrm{n}=188 ; \mathrm{P}<.01$; Fisher's Exact test). Interestingly, some of the females that remained with their first egg mass were never observed with ant mutualists.

To evaluate the influence of RV on female tenure with eggs, we compared the number of eggs in masses guarded through hatch by females that were not ant attended to the number of eggs in masses that were abandoned by females that deposited a second clutch. Again, egg masses deposited by females that abandoned eggs but were not recovered were excluded from the analysis because we did not know if the mass had been abandoned by the parent female or if the female had been removed from the egg mass. Egg masses guarded through hatch by females that were never located by ants were larger $(\bar{x}=46.85 \pm 2.06$ eggs $)$ than those abandoned by females that deposited a second clutch $\left(\bar{x}=30.89 \pm 2.52\right.$ eggs; $F_{(1,85)}=23.96$, $\mathrm{P}<.001$; ANOVA). If $E$. bactriana females have a finite number of eggs or a limited time in which to deposit them, females with larger egg masses have lower RV's than do females with smaller egg masses. Females with large egg masses, and presumably lower RV's, are less likely to abandon clutches, even if they are not consistently tended by ants. In contrast, females with small egg masses (higher RV's) are more likely to abandon clutches to deposit others if not located by ants.

To evaluate the consequences of intraspecific variation in ovipositional behavior, we compared the number of nymphs and ant attendance of first instars from egg masses deposited by females that remained through egg hatch with their first egg mass and from egg 
masses deserted prior to hatch by females that deposited a second clutch. The number of first instar nymphs did not differ significantly between females that remained with their first egg mass $(\bar{x}=32.00$ \pm 1.11 nymphs) and those that abandoned their first but remained with their second egg mass $\left(\bar{x}=28.85 \pm 2.99\right.$ nymphs, $F_{(1,210)}=.98$, N.S.; ANOVA). Additionally, nymphs from second egg masses $(96.15 \%, \mathrm{n}=26)$ were as likely to be located by ants as were nymphs of females that remained through hatch with their first egg mass (89.84\%, $\mathrm{n}=187, \mathrm{P}=.479$; Fisher's Exact test). Thus, although some females 'sacrifice' their first egg mass, they do not differ significantly from females that guard a single egg mass in offspring number or nymphal ant attendance.

Although many species are dependent upon mutualisms, factors independent of these associations also influence and constrain members of the interacting populations (May 1981, Price 1984). For example, E. bactriana nymphal maturation is contingent upon protection by ants (Wood 1977, Olmstead 1984); yet ant mutualism is not the best predictor of egg guarding behavior by parent females. Rather, the RV of E. bactriana females appears to limit their ability to respond to ant mutualists. Females with larger egg masses, and lower RV's, do not desert eggs even if they are not tended by ants. The inclusion of reproductive parameters in studies of ant attended treehoppers may provide more realistic explanations for the intraspecific variation in parental care.

\section{SUMMARY}

Entylia bactriana guard young and interact with ant mutualists. Parent females that guard eggs have increased egg hatch and may attract ants to their offspring as nymphs with mothers are more frequently located by ants. Desertion of eggs prior to hatch is costly in that fewer eggs hatch; location by ants of nymphs from these egg masses is low; and consequently, few nymphs survive. Yet, some females desert egg masses to deposit other clutches. Previous studies have shown that ants influence the subsocial behavior of treehoppers, yet little is known about the influence of ants on the ovipositional behavior of these species. Although the maturation of $E$. bactriana nymphs is contingent upon ant attendance, tenure with egg masses is largely a function of egg mass size. Females are less 
likely to abandon large egg masses than are females with smaller egg masses. Although E. bactriana is an obligate ant mutualist, its ovipositional behavior is constrained by the reproductive value of the female.

\section{ACKNOWLEDGEMENTS}

We would like to thank L. E. Hurd, D. W. Tallamy, R. F. Denno, E. Russek-Cohen, and B. Benrey for their helpful comments on various drafts of this manuscript. Thanks also go to M. C. Keese and E. M. Olmstead for assistance in the field and D. F. Bray for the ant identifications. This work was supported by National Science Foundation grant DEB 8021398 to T.K.W. The computer time for this project was provided in part by the Computer Science Center at the University of Maryland. This report is Miscellaneous Paper No. 1073, Contribution No. 557 of the Department of Entomology and Applied Ecology, University of Delaware, Newark, DE.

\section{Literature Cited}

Begon, M., J. L. HARPER, AND C. R. TOWNSEND

1986. Ecology: Individuals, populations and communities. Sinauer Associates, Sunderland, Massachusetts.

BRISTOW, C. M.

1983. Treehoppers transfer parental care to ants: a new benefit of mutualism. Science 220: 532-533.

BRISTOw, C. M.

1984. The life histories of two species of Homoptera on ironweed (Vernonia spp.) with summaries of host and geographic ranges. J. Kans. Entomol. Soc. 57: 632-638.

Cushman, J. H. and T. G. Whitham

1989. Conditional mutualism in a membracid-ant association: temporal, agespecific, and density-dependent effects. Ecology 70: 1040-1047.

Eberhard, W. G.

1986. Possible mutualism between females of the subsocial membracid Polyglypta dispar (Homoptera). Behav. Ecol. Sociobiol. 19: 447-453.

EICKWORT, G. W.

1981. Presocial insects. In, H. R. Hermann (ed.), Social Insects, Vol. II. Academic Press, New York, pp. 199-280.

Fritz, R. S.

1982. An ant-treehopper mutualism: effects of Formica subsericea on the survival of Vanduzea arquata. Ecol. Entomol 7: 267-276.

FrITZ, R. S.

1983. Ant protection of a host plant's defoliator: consequence of an antmembracid mutualism. Ecology 64: 789-797. 
Hinton, H. E.

1977. Subsocial behavior and biology of some Mexican membracid bugs. Ecol. Entomol. 2: 61-79.

Hinton, H. E.

1981. Biology of insect eggs, Vol. I. Pergamon Press, Oxford.

Holm, L. G., D. L. Plucknett, J. V. Pancho, and J. B. Herberger

1977. The world's worst weeds. East-West Book Center, Honolulu.

JoHnson, R. A. AND D. W. WICHERN

1988. Applied multivariate statistical analysis, Prentice Hall, Englewood Cliffs, New Jersey.

Lanza, J. and B. R. KRauss

1984. Detection of amino acids in artificial nectars by two tropical ants, Leptothorax and Monomorium. Oecologia (Berlin) 63: 423-425.

MAY, R. M.

1981. Theoretical ecology, principles and applications, Second edition. Sinauer, Sunderland, Massachusetts.

McEvoy, P. B.

1979. Advantages and disadvantages to group living in treehoppers (Homoptera: Membracidae). Misc. Pub. Entomol. Soc. Amer. 11: 1-13.

Olmstead, K. L.

1984. Maternal behavior to establish ant/membracid associations. MS Thesis, University of Delaware, Newark, DE.

Price, P. W.

1984. Insect Ecology, Second Edition. Wiley-Interscience, New York.

SAS INSTITUTE

1988. SAS/STAT User's Guide, Release 6.03 Edition. SAS Institute, Cary, North Carolina.

Sudd, J. H. AND M. E. SudD

1985. Seasonal changes in the response of wood-ants to sucrose baits. Ecol. Entomol. 10: 298-307.

Tallamy, D. W.

1982. Age specific maternal defense in Gargaphia solani (Hemiptera: Tingidae). Behav. Ecol. Sociobiol. 11: 7-11.

Tallamy, D. W. AND T. K. Wood

1986. Convergence patterns in subsocial insects. Ann. Rev. Entomol. 31: 369-390.

WAY, M. J.

1963. Mutualism between ants and honeydew producing Homoptera. Ann. Rev. Entomol. 8: 307-344.

Wood, T. K.

1977. Role of parent females and attendant ants in the maturation of the treehopper, Entylia bactriana (Homoptera: Membracidae). Sociobiology 2: 257-272.

WooD, T. K.

1979. Sociality in the Membracidae (Homoptera). Misc. Pub. Entomol. Soc. Amer. 11: 15-22. 
Wood, T. K.

1982a. Selective factors associated with the evolution of membracid sociality. In, M. D. Breed, C. D. Michener, and H. E. Evans (eds.), The biology of social insects, Westview Press, Boulder. pp. 175-179.

Wood, T. K.

1982b. Ant-attended nymphal aggregations in the Enchenopa binotata complex (Homoptera: Membracidae). Ann. Entomol. Soc. Amer. 75: 649-653. 

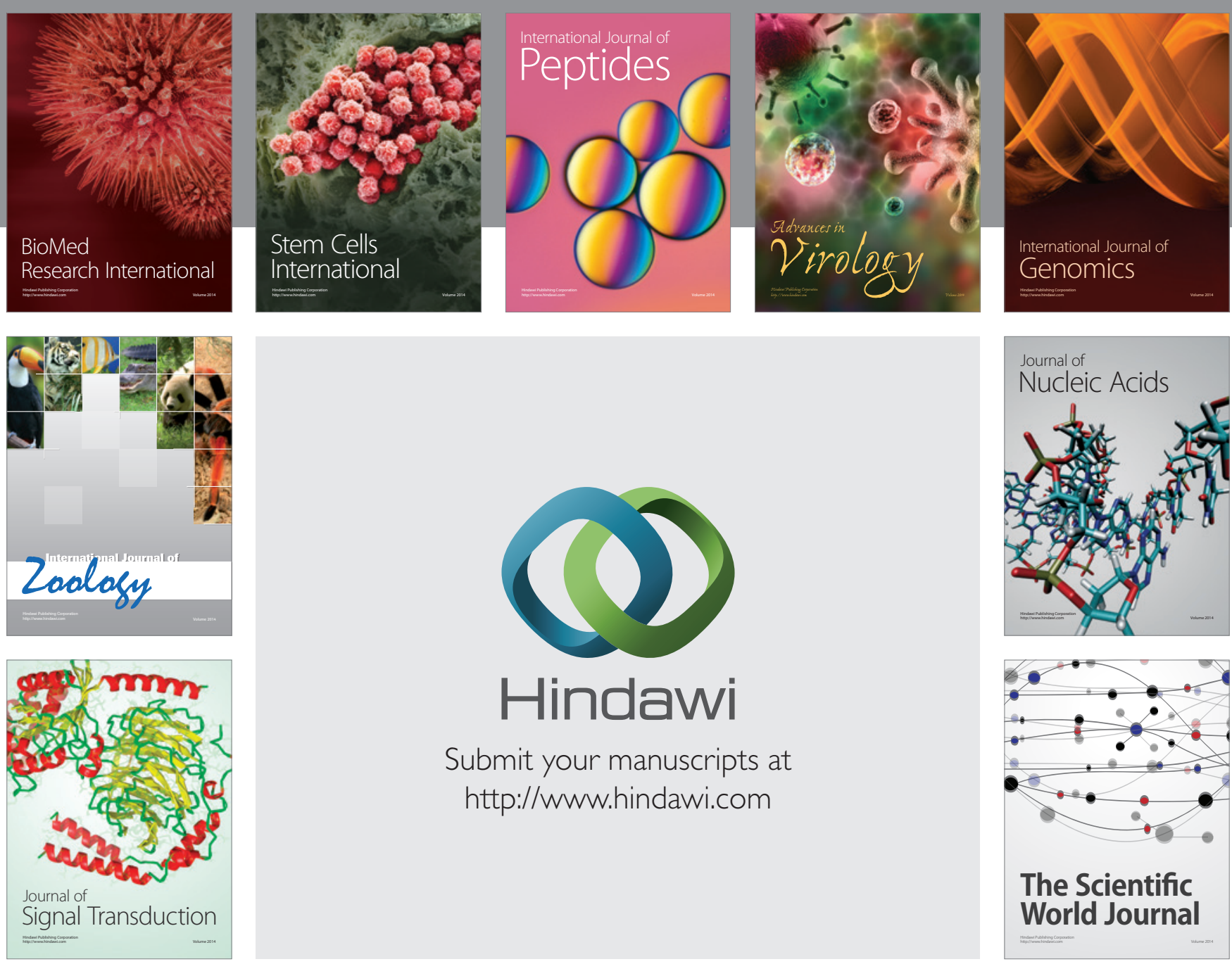

Submit your manuscripts at

http://www.hindawi.com
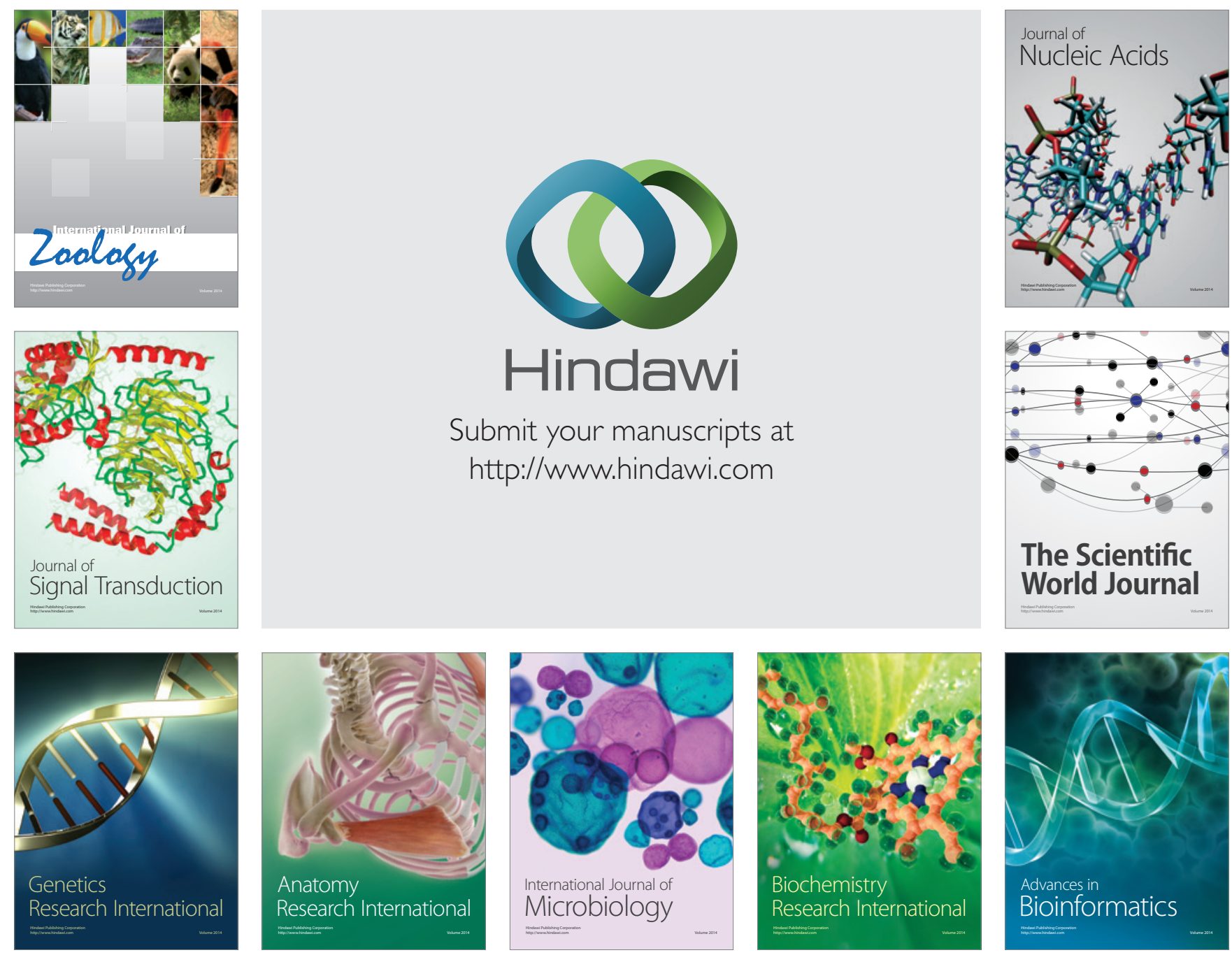

The Scientific World Journal
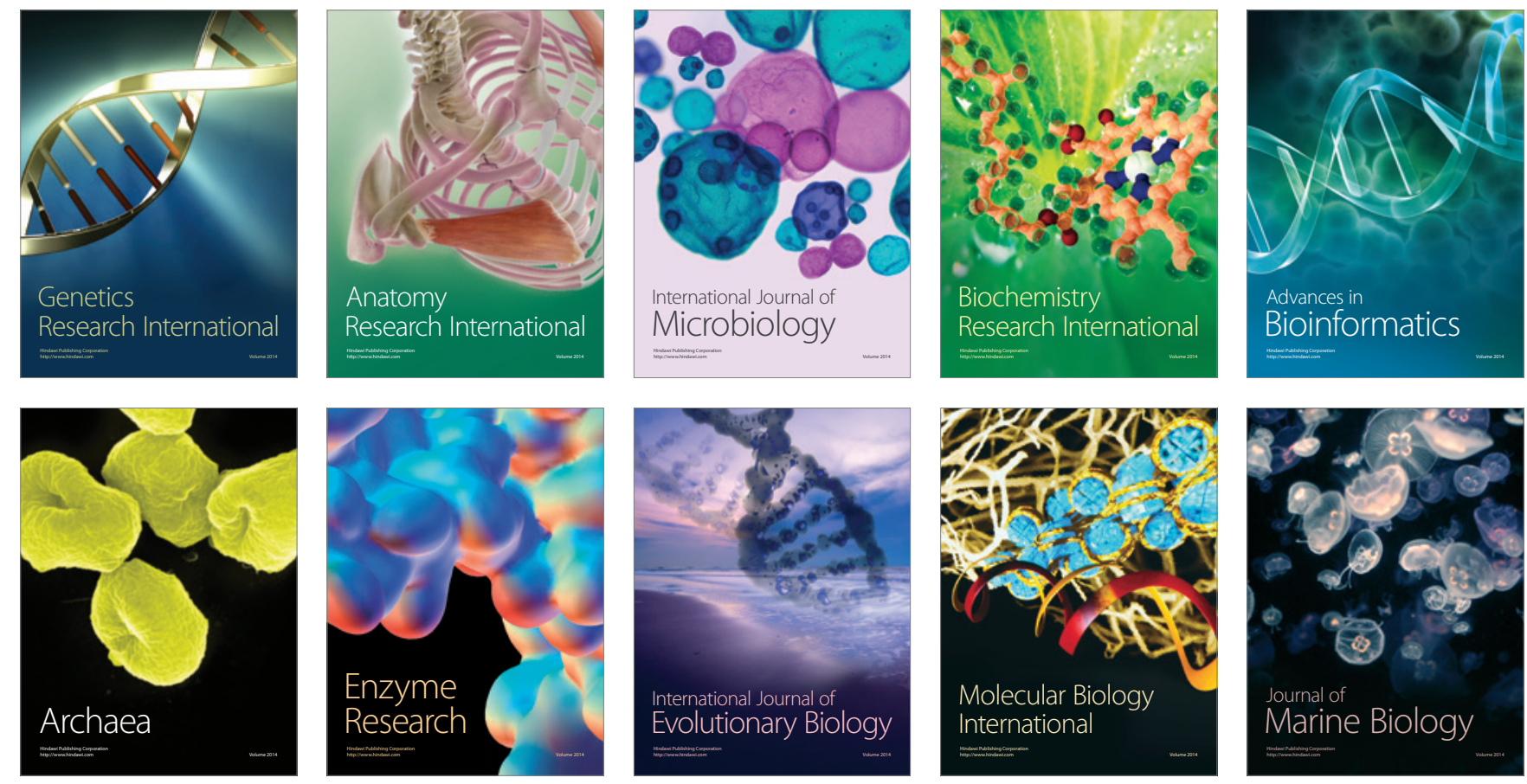